Supporting Information:

Controllable and Repeatable Synthesis of Thermally Stable Anatase Nanocrystal-Silica Composites with Highly Ordered

\title{
Hexagonal Mesostructures
}

Weiyang Dong*广, Yaojun Sun ${ }^{\S}$, Chul Wee Lee" , Weiming Hua ${ }^{\ddagger}$, Xinchun Lu ${ }^{\S}$, Yifeng Shit, Shicheng Zhang ${ }^{\dagger}$, Jianmin Chen ${ }^{\dagger}$, Dongyuan Zhao ${ }^{*}$

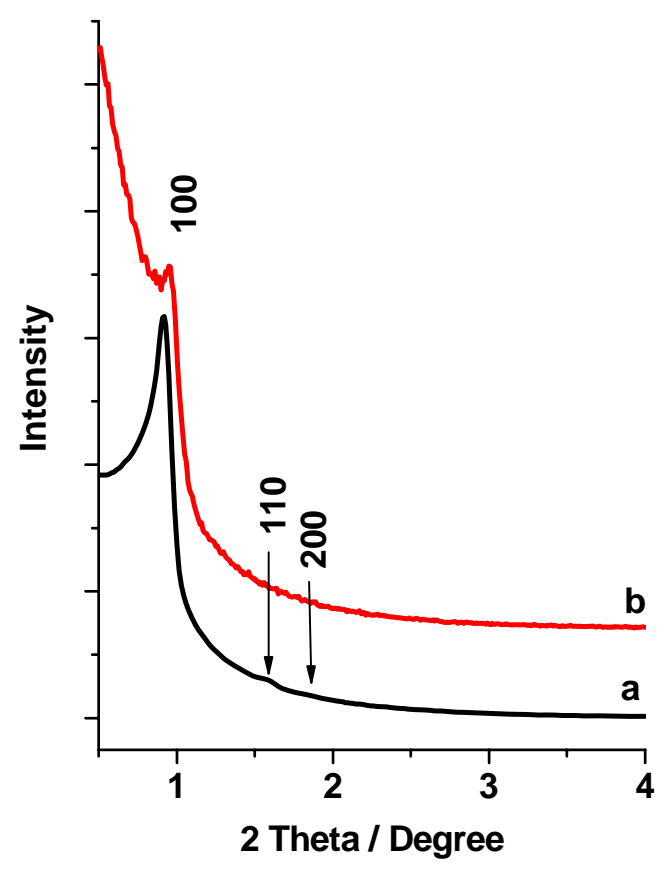

Figure S1. SAXRD patterns of mesostructured pure $\mathrm{TiO}_{2}$ samples calcined at $400{ }^{\circ} \mathrm{C}$ (a) and $450{ }^{\circ} \mathrm{C}$ (b) for $2 \mathrm{~h}$, respectively. 


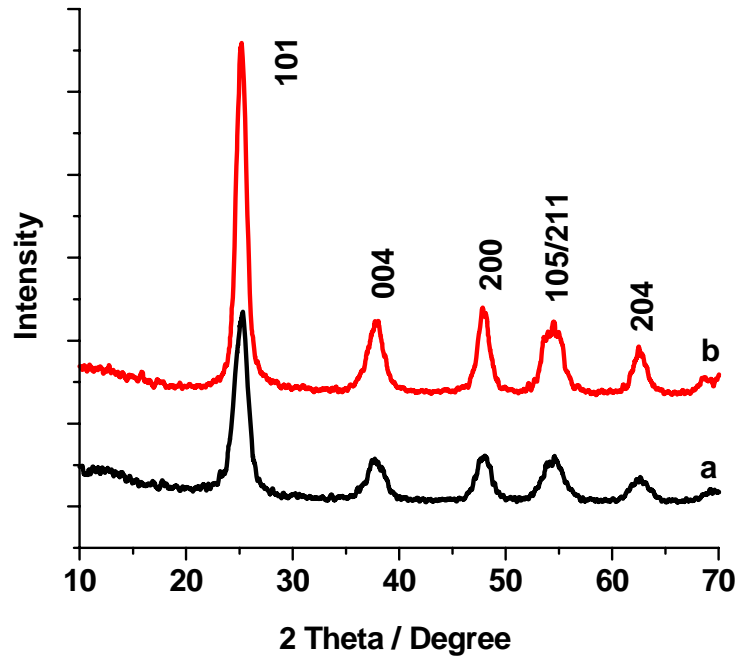

Figure S2. WAXRD patterns of mesostructured $\mathrm{TiO}_{2}$ products calcined at $400{ }^{\circ} \mathrm{C}$ (a) and $450{ }^{\circ} \mathrm{C}$ (b) for $2 \mathrm{~h}$, respectively; corresponding to Figure S1. 

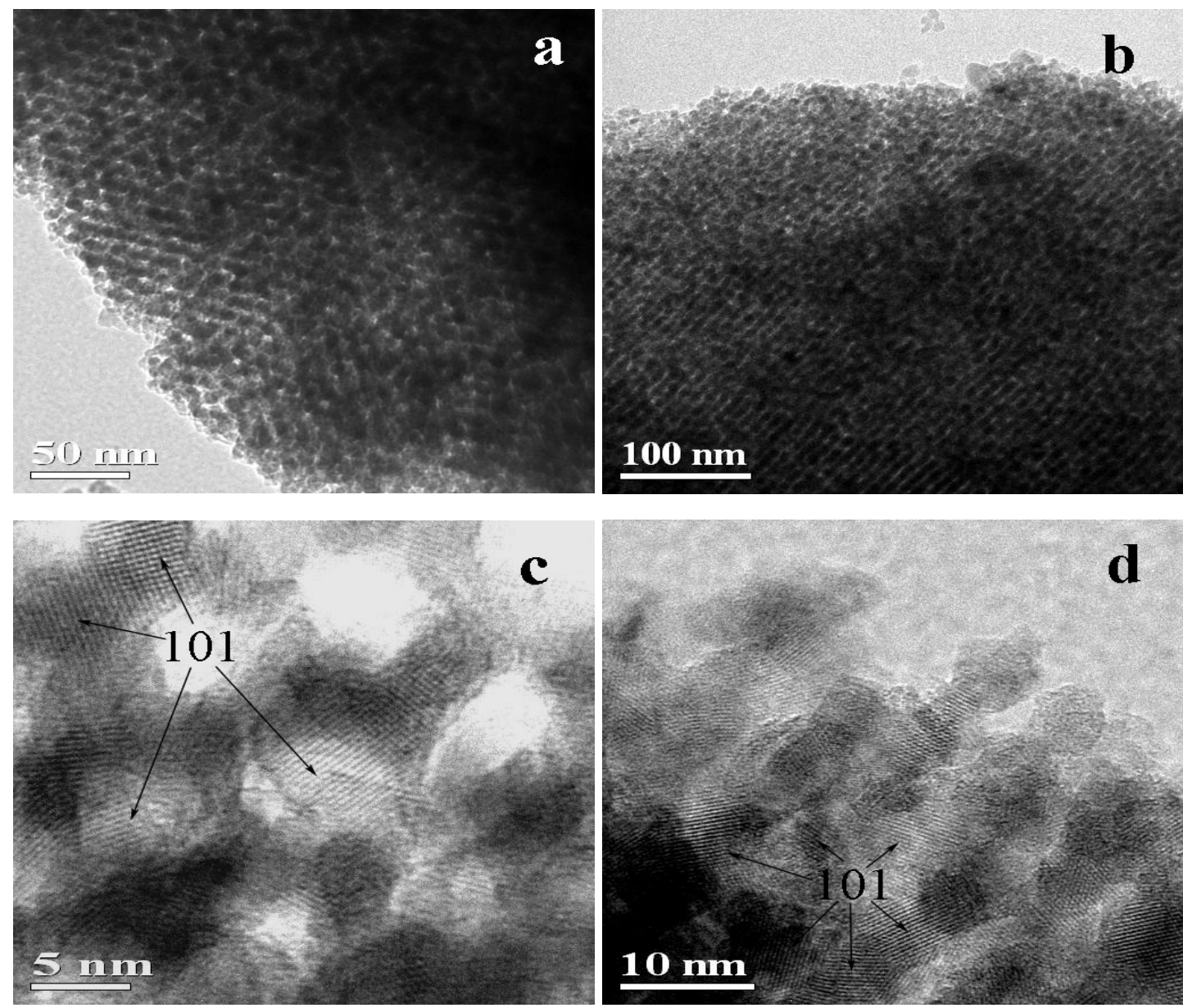

Figure S3. TEM (a, b) and HRTEM (c, d) images of mesoporous $\mathrm{TiO}_{2}$ product calcined at $450{ }^{\circ} \mathrm{C}$ for $2 \mathrm{~h}$; viewed along [001] direction (a, c), and along [110] direction (b, d). 


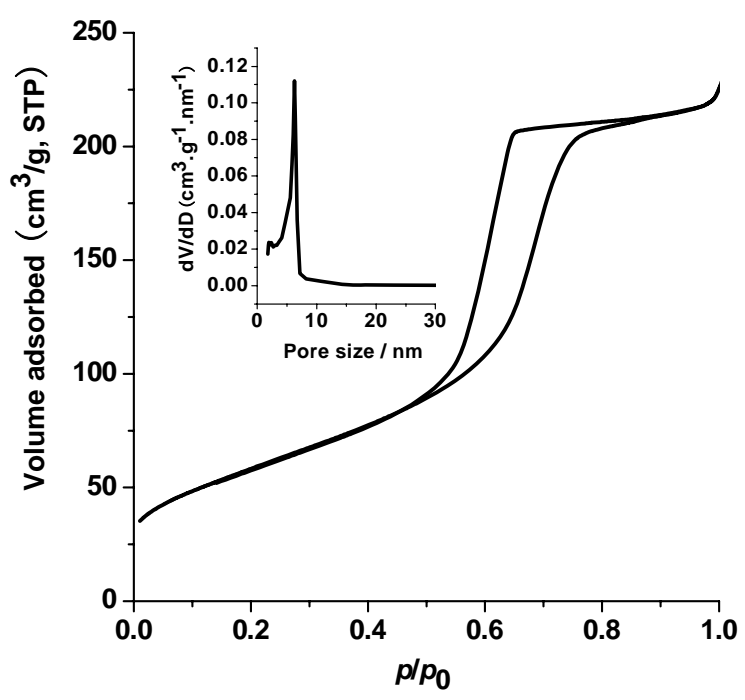

Figure S4. $\mathrm{N}_{2}$ adsorption-desorption isotherms and pore size distribution (inset) of the mesoporous $\mathrm{TiO}_{2}$ structure calcined at $400{ }^{\circ} \mathrm{C}$ for $2 \mathrm{~h}$.

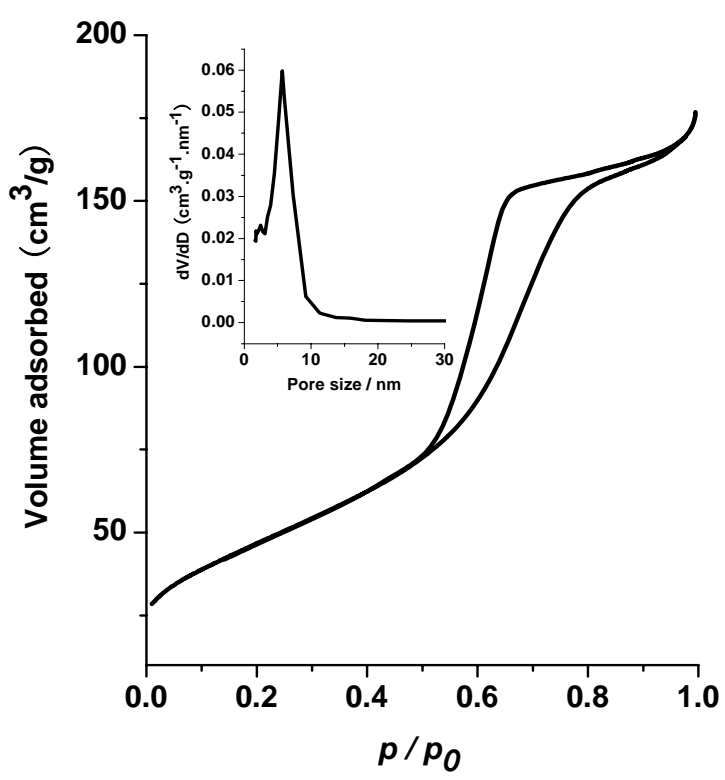

Figure S5. $\mathrm{N}_{2}$ adsorption-desorption isotherms and pore size distribution (inset) of the mesoporous $\mathrm{TiO}_{2}$ structure calcined at $450{ }^{\circ} \mathrm{C}$ for $2 \mathrm{~h}$. 

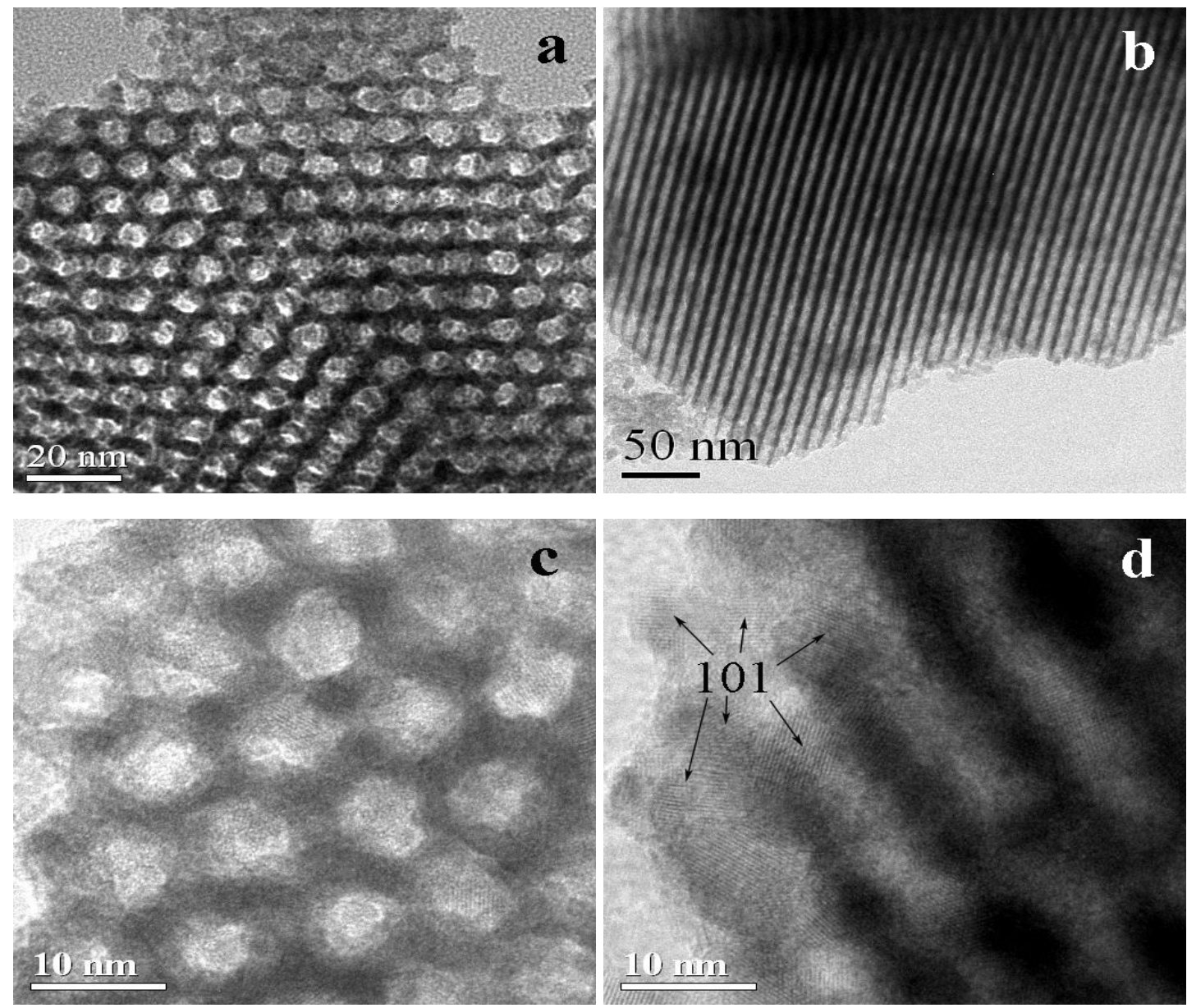

Figure S6. TEM (a, b) and HRTEM (c, d) images of 2-D hexagonal mesoporous $90 \mathrm{TiO}_{2}-10 \mathrm{SiO}_{2}$ composites calcined at $500^{\circ} \mathrm{C}$ for $4 \mathrm{~h}$; viewed along [001] direction (a, c), and along [110] direction (b, d). 

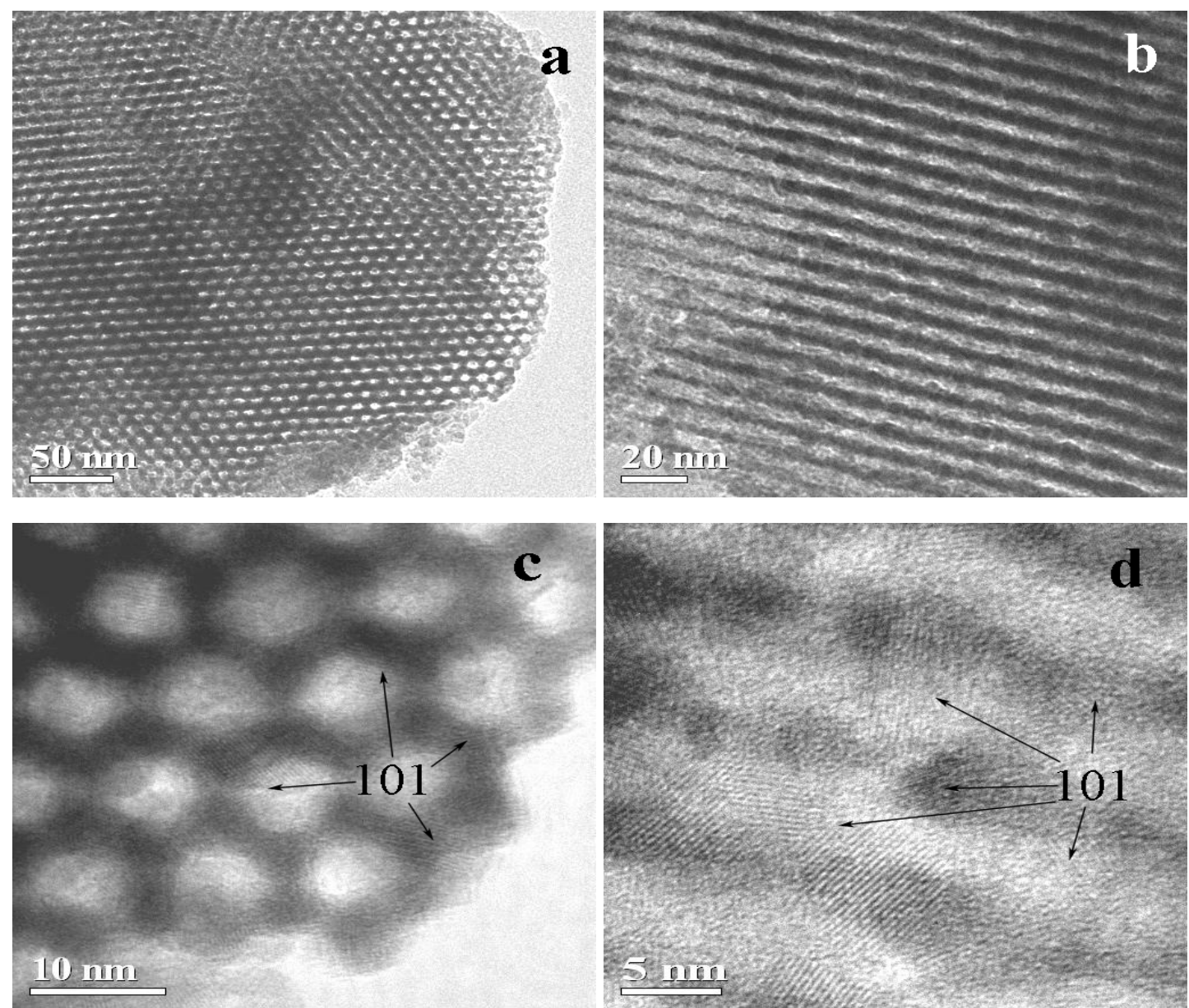

Figure S7. TEM (a, b) and HRTEM (c, d) images of 2-D hexagonal mesoporous

$70 \mathrm{TiO}_{2}-30 \mathrm{SiO}_{2}$ composite calcined at $800{ }^{\circ} \mathrm{C}$ for $2 \mathrm{~h}$; viewed along [001] direction (a, c), and along [110] direction (b, d). 

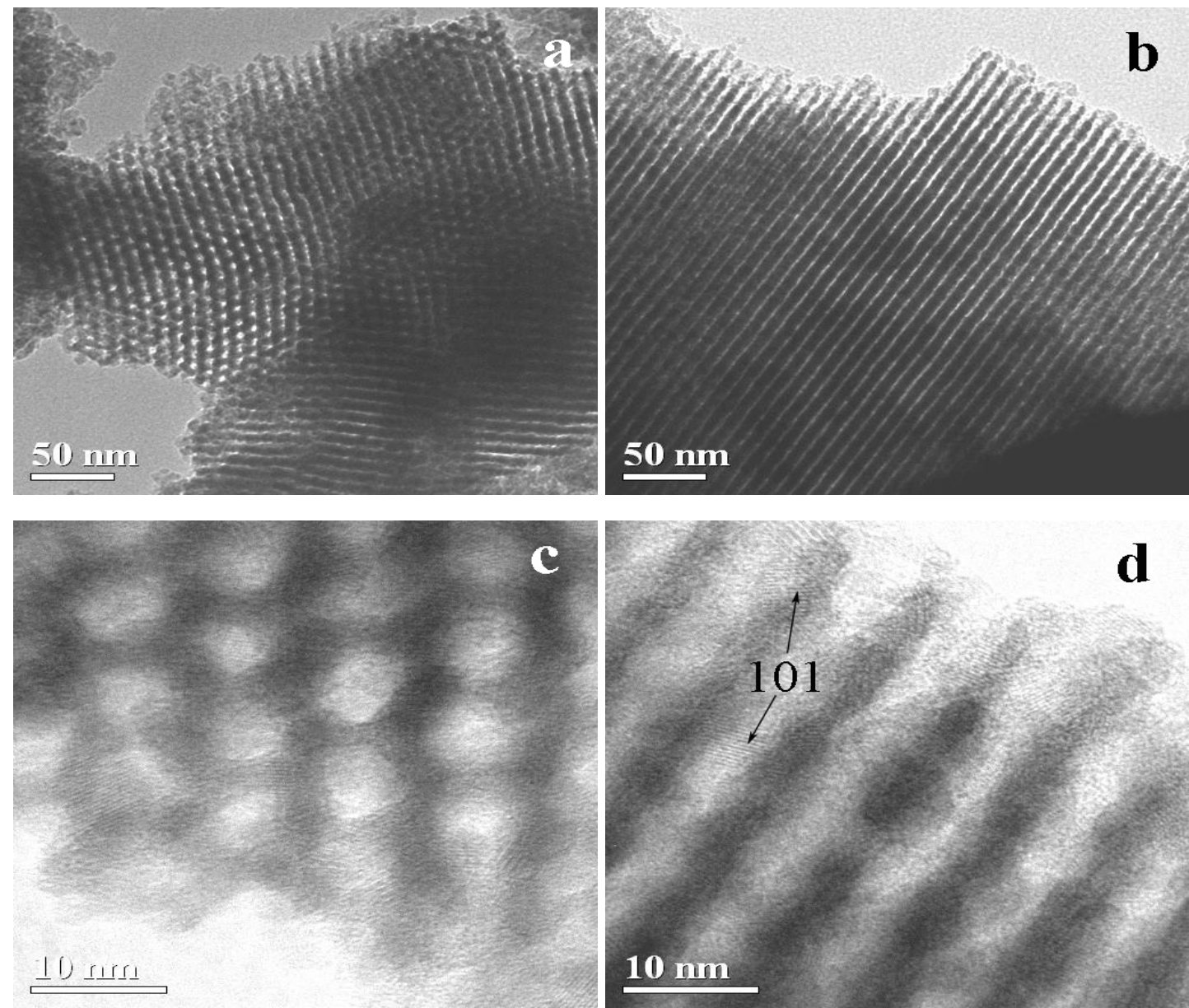

Figure S8. TEM (a, b) and HRTEM (c, d) images of 2-D hexagonal mesoporous $60 \mathrm{TiO}_{2}-40 \mathrm{SiO}_{2}$ composite heat-treated at $800{ }^{\circ} \mathrm{C}$ for $2 \mathrm{~h}$; viewed along [001] direction (a, c), and along [110] direction (b, d). 

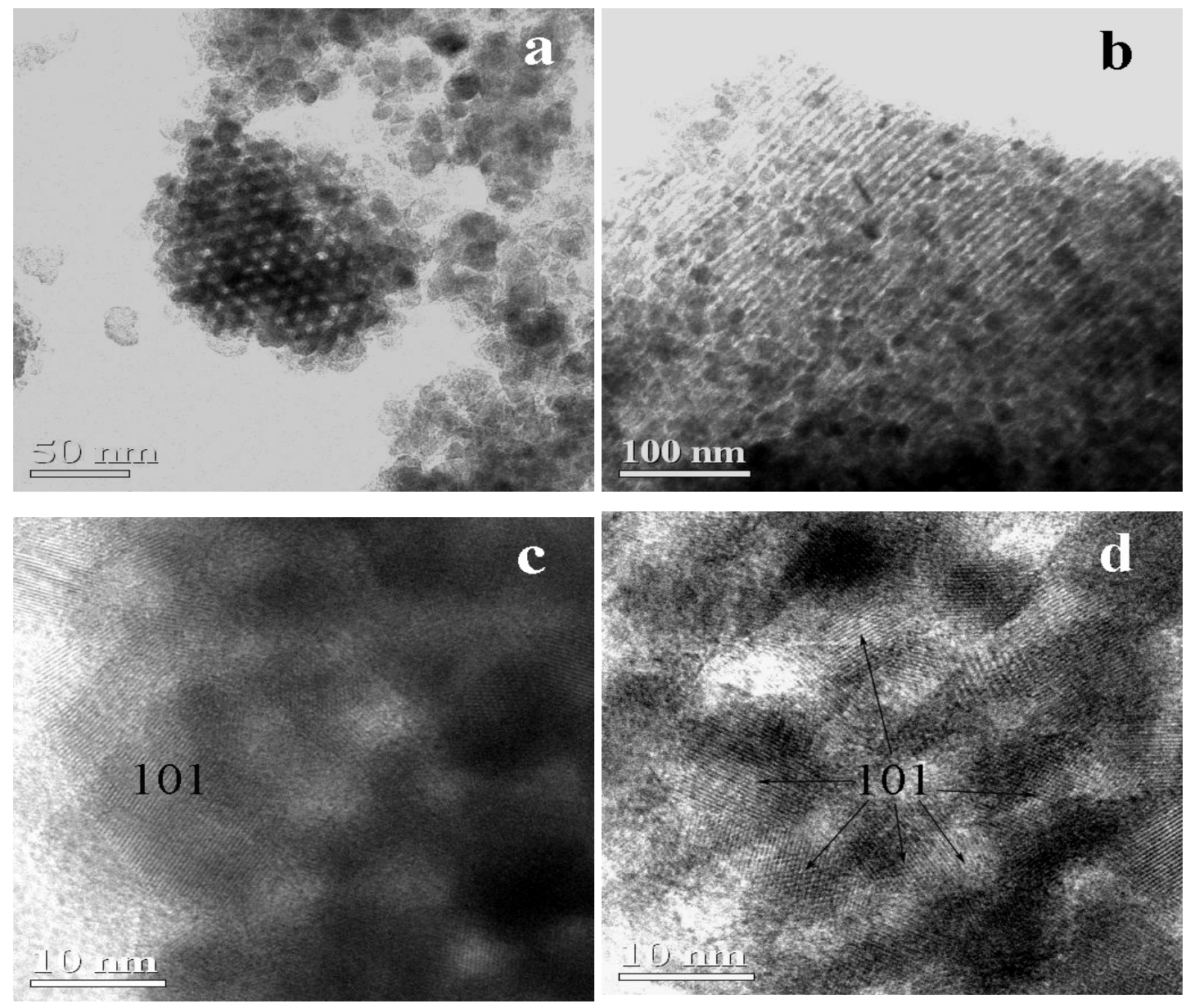

Figure S9. TEM (a, b) and $\operatorname{HRTEM}(c, d)$ images of mesoporous $80 \mathrm{TiO}_{2}-20 \mathrm{SiO}_{2}$ composite calcined at $900{ }^{\circ} \mathrm{C}$ for $2 \mathrm{~h}$; viewed along [001] direction (a, c), and along [110] direction (b, d). 

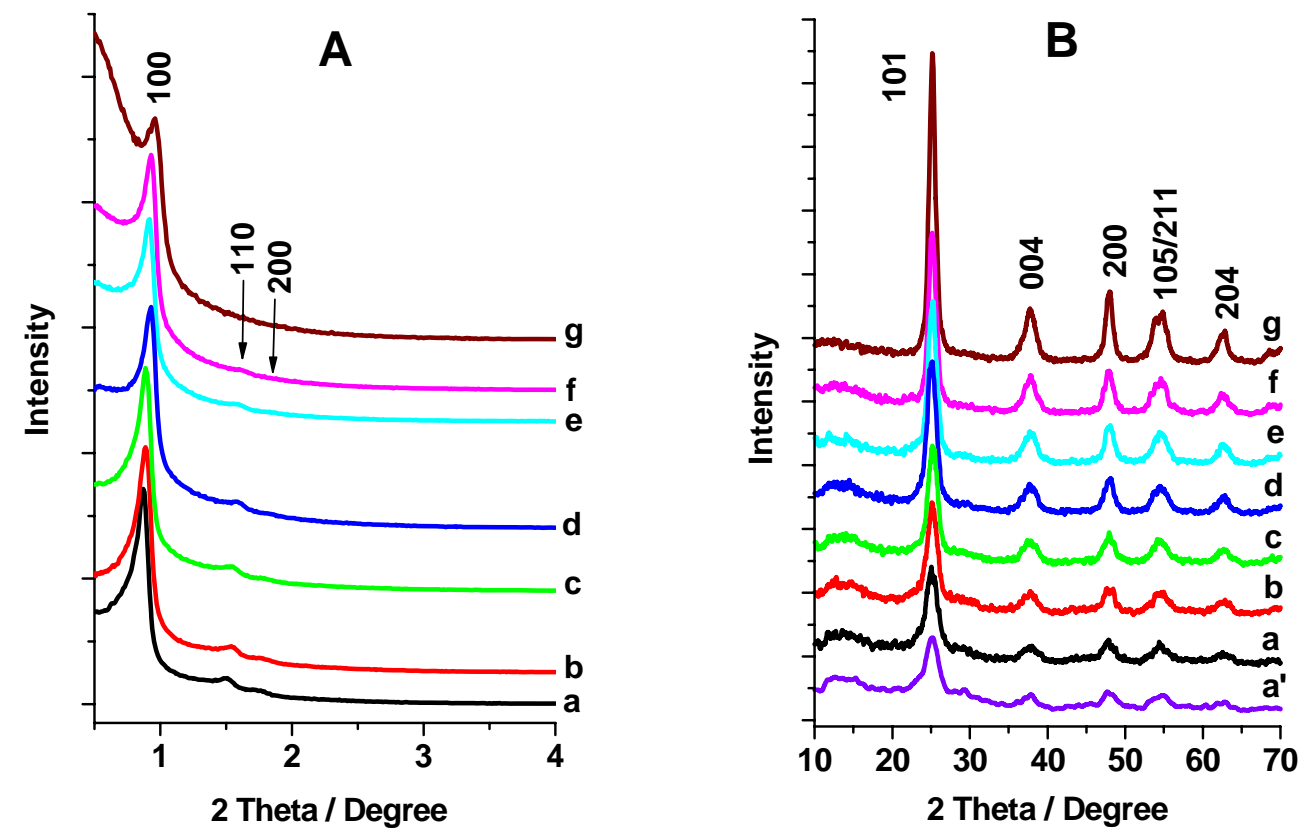

Figure S10. SAXRD (A) and WAXRD (B) patterns of mesoporous $90 \mathrm{TiO}_{2}-10 \mathrm{SiO}_{2}$ composites calcined in air at $350{ }^{\circ} \mathrm{C}$ for $6 \mathrm{~h}$ (a'), $450{ }^{\circ} \mathrm{C}$ for $4 \mathrm{~h}$ (a), $500{ }^{\circ} \mathrm{C}$ for $4 \mathrm{~h}$ (b), $550{ }^{\circ} \mathrm{C}$ for $4 \mathrm{~h}$ (c), $600^{\circ} \mathrm{C}$ for $4 \mathrm{~h}(\mathrm{~d}), 650^{\circ} \mathrm{C}$ for $4 \mathrm{~h}(\mathrm{e}), 700^{\circ} \mathrm{C}$ for $2 \mathrm{~h}(\mathrm{f}), 750{ }^{\circ} \mathrm{C}$ for $2 \mathrm{~h}(\mathrm{~g})$. 

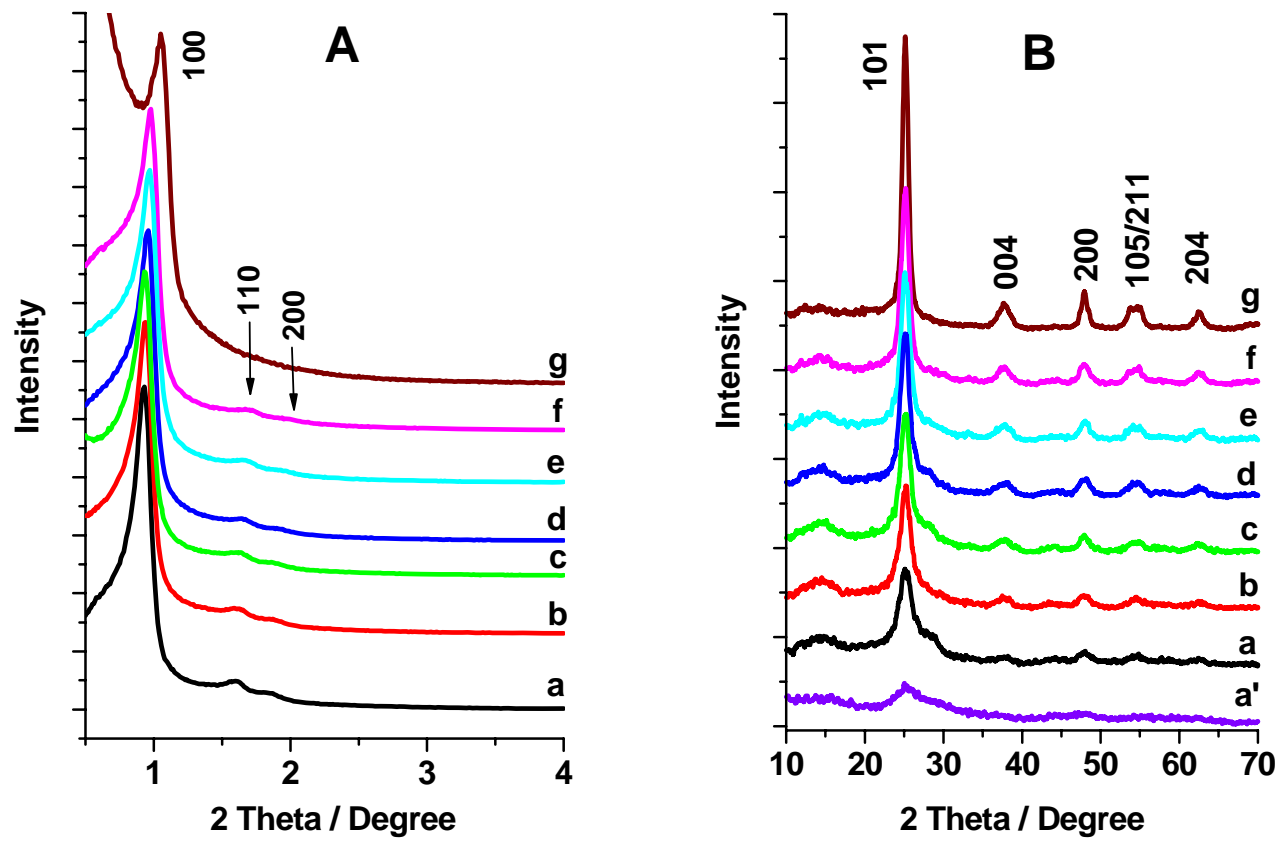

Figure S11. SAXRD (A) and WAXRD (B) patterns of mesoporous $70 \mathrm{TiO}_{2}-30 \mathrm{SiO}_{2}$ composites calcined in air at $350{ }^{\circ} \mathrm{C}$ for $6 \mathrm{~h}$ (a'), $600{ }^{\circ} \mathrm{C}$ for $4 \mathrm{~h} \mathrm{(a),} 650{ }^{\circ} \mathrm{C}$ for $4 \mathrm{~h}(\mathrm{~b})$, $700{ }^{\circ} \mathrm{C}$ for $4 \mathrm{~h}(\mathrm{c}), 750{ }^{\circ} \mathrm{C}$ for $2 \mathrm{~h}(\mathrm{~d}), 800{ }^{\circ} \mathrm{C}$ for $2 \mathrm{~h}(\mathrm{e}), 850^{\circ} \mathrm{C}$ for $2 \mathrm{~h}(\mathrm{f}), 900{ }^{\circ} \mathrm{C}$ for $2 \mathrm{~h}(\mathrm{~g})$. 

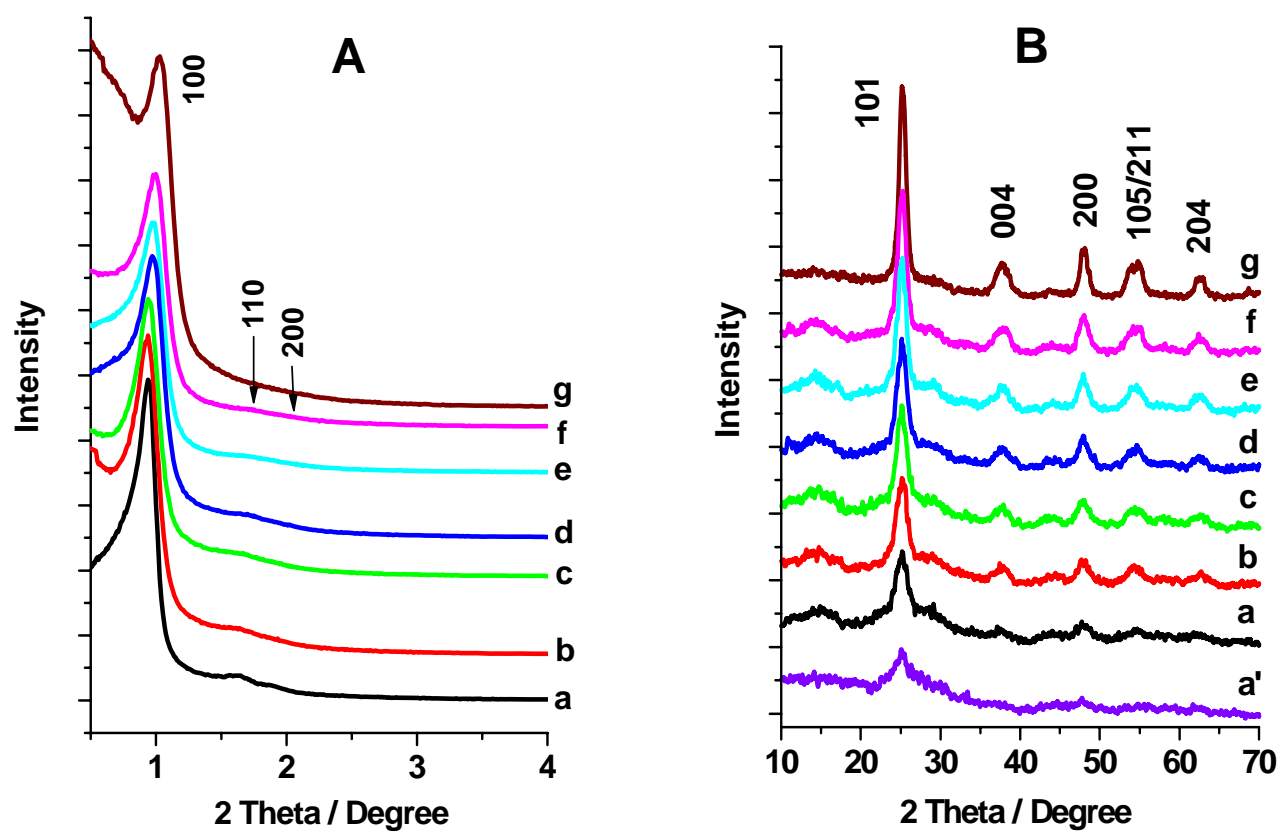

Figure S12. SAXRD (A) and WAXRD (B) patterns of mesoporous $60 \mathrm{TiO}_{2}-40 \mathrm{SiO}_{2}$ composites calcined in air at $350{ }^{\circ} \mathrm{C}$ for $6 \mathrm{~h}$ (a'), $600{ }^{\circ} \mathrm{C}$ for $4 \mathrm{~h}(\mathrm{a}), 650{ }^{\circ} \mathrm{C}$ for $4 \mathrm{~h}$ (b), $700{ }^{\circ} \mathrm{C}$ for $4 \mathrm{~h}(\mathrm{c}), 750{ }^{\circ} \mathrm{C}$ for $2 \mathrm{~h}(\mathrm{~d}), 800^{\circ} \mathrm{C}$ for $2 \mathrm{~h} \mathrm{(e),} 850{ }^{\circ} \mathrm{C}$ for $2 \mathrm{~h} \mathrm{(f),} 900{ }^{\circ} \mathrm{C}$ for $2 \mathrm{~h}(\mathrm{~g})$. 

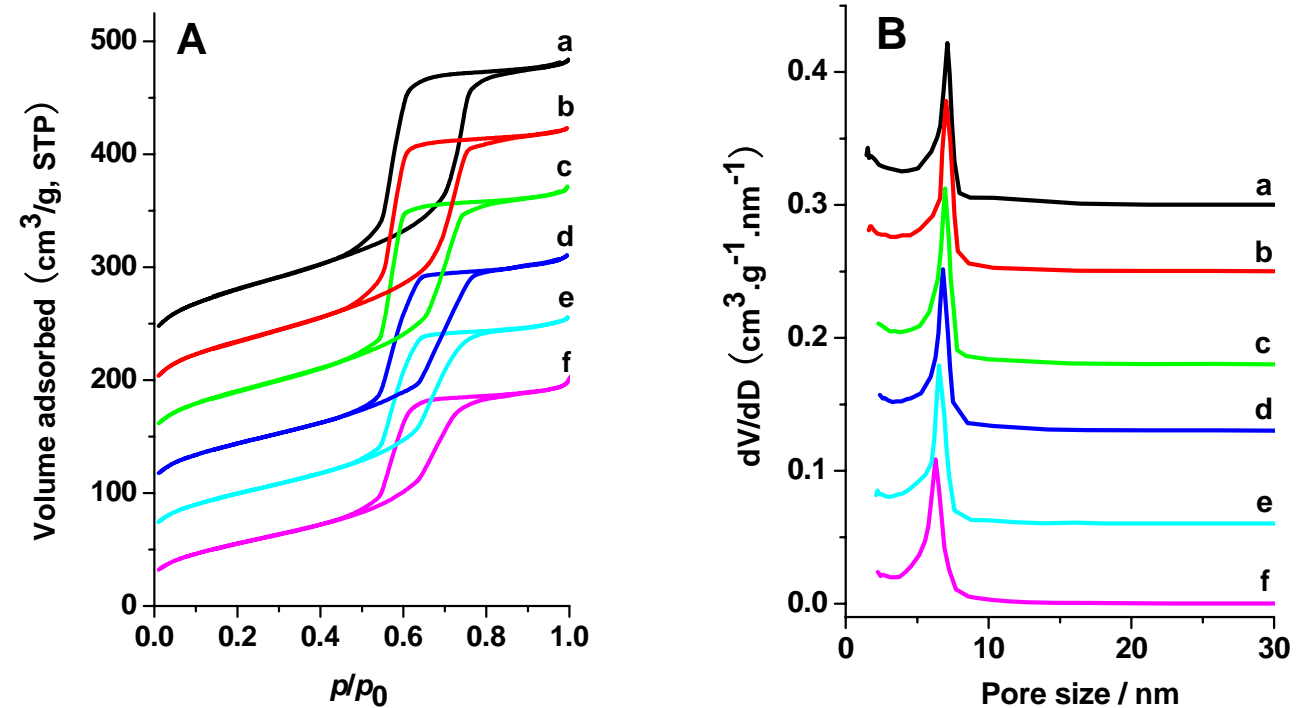

Figure S13. $\mathrm{N}_{2}$ adsorption-desorption isotherms (A) and pore size distributions (B) of mesoporous $90 \mathrm{TiO}_{2}-10 \mathrm{SiO}_{2}$ composites calcined in air at $450{ }^{\circ} \mathrm{C}$ for $4 \mathrm{~h}(\mathrm{a}), 500{ }^{\circ} \mathrm{C}$ for $4 \mathrm{~h}$ (b), $550{ }^{\circ} \mathrm{C}$ for $4 \mathrm{~h}$ (c), $600{ }^{\circ} \mathrm{C}$ for $4 \mathrm{~h} \mathrm{(d),} 650{ }^{\circ} \mathrm{C}$ for $4 \mathrm{~h}(\mathrm{e})$ and $700{ }^{\circ} \mathrm{C}$ for $2 \mathrm{~h}$ (f). The isotherms a, b, c, d and e are offset vertically by 200, 160, 120, 80 and 40 $\mathrm{cm}^{3} / \mathrm{g}$, respectively. 

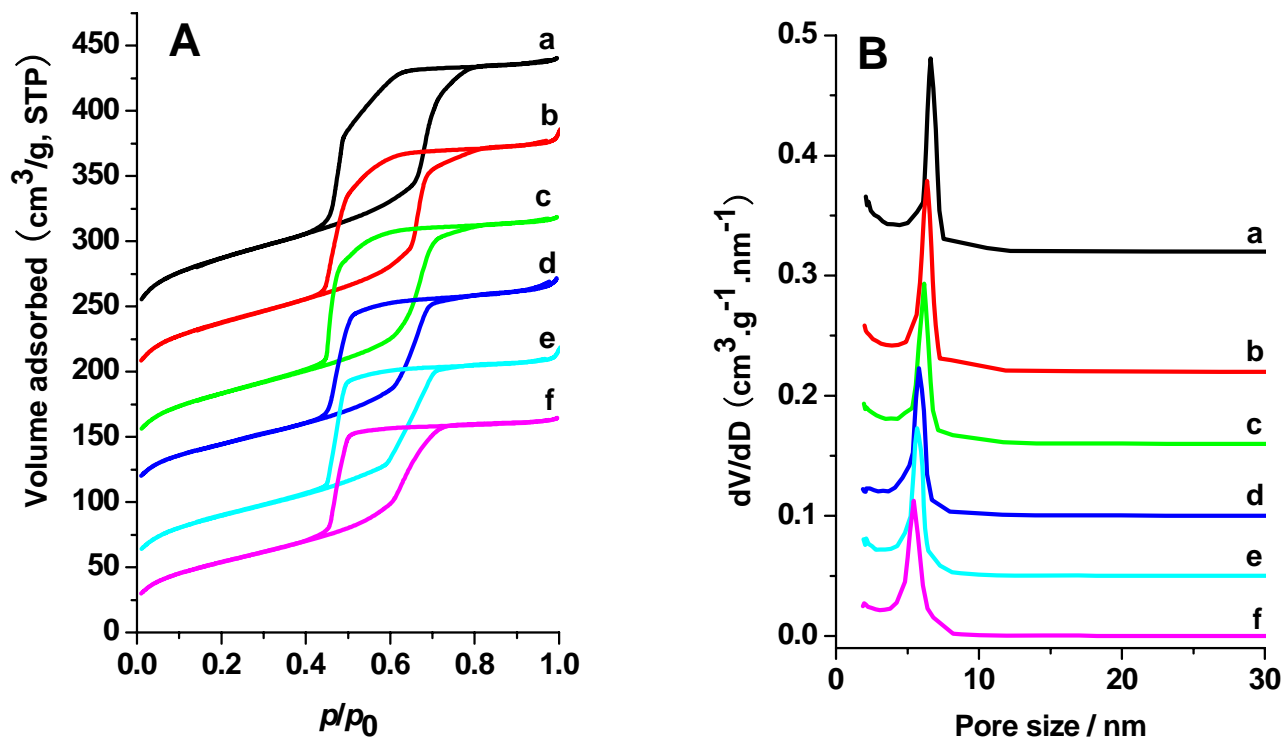

Figure S14. $\mathrm{N}_{2}$ adsorption-desorption isotherms (A) and pore size distributions (B) of the mesoporous $70 \mathrm{TiO}_{2}-30 \mathrm{SiO}_{2}$ composites calcined in air at $600{ }^{\circ} \mathrm{C}$ for $4 \mathrm{~h} \mathrm{(a),} 650$ ${ }^{\circ} \mathrm{C}$ for $4 \mathrm{~h}$ (b), $700{ }^{\circ} \mathrm{C}$ for $4 \mathrm{~h}$ (c), $750{ }^{\circ} \mathrm{C}$ for $2 \mathrm{~h} \mathrm{(d),} 800{ }^{\circ} \mathrm{C}$ for $2 \mathrm{~h} \mathrm{(e),} 850{ }^{\circ} \mathrm{C}$ for $2 \mathrm{~h}$ (f). The isotherms a, b, c, d and e are offset vertically by 210, 170, 120, 90 and 30 $\mathrm{cm}^{3} / \mathrm{g}$, respectively. 

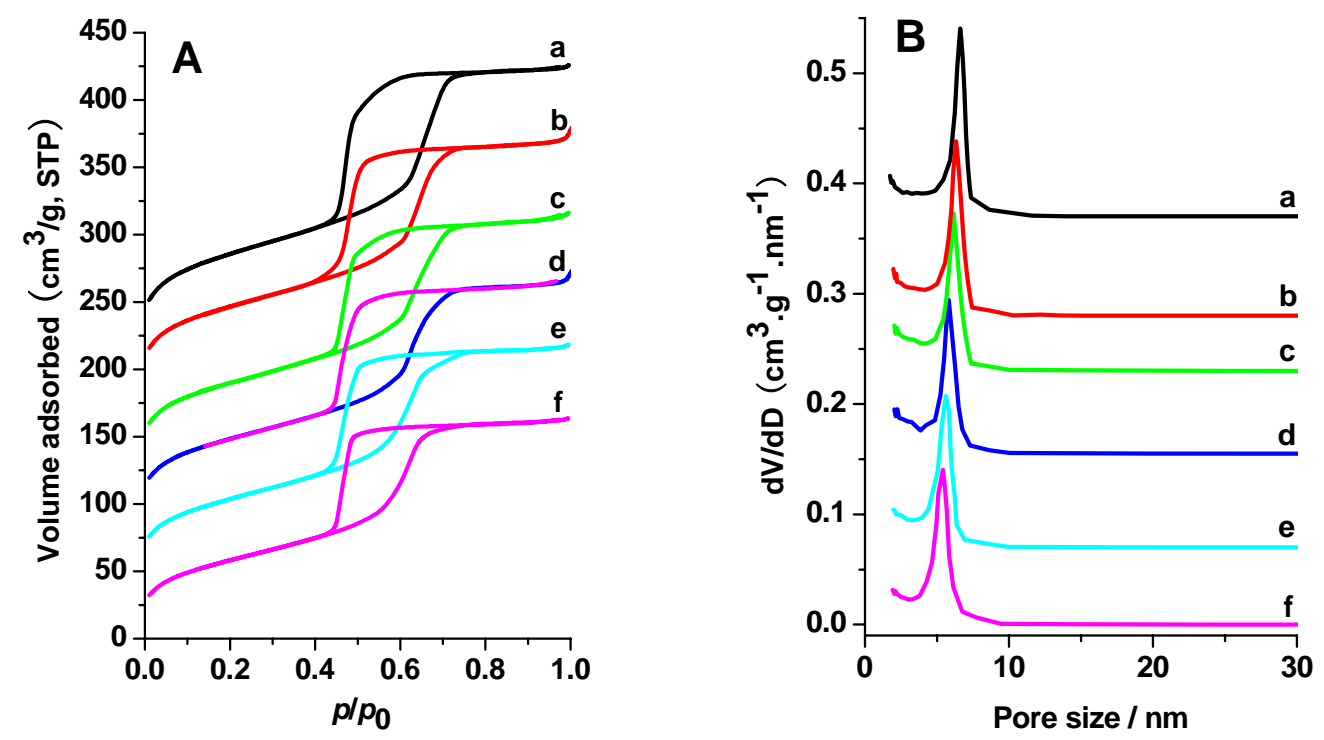

Figure S15. $\mathrm{N}_{2}$ adsorption-desorption isotherms (A) and pore size distributions (B) of the mesoporous $60 \mathrm{TiO}_{2}-40 \mathrm{SiO}_{2}$ composites calcined in air at $600{ }^{\circ} \mathrm{C}$ for $4 \mathrm{~h} \mathrm{(a),} 650$ ${ }^{\circ} \mathrm{C}$ for $4 \mathrm{~h}$ (b), $700{ }^{\circ} \mathrm{C}$ for $4 \mathrm{~h}$ (c), $750{ }^{\circ} \mathrm{C}$ for $2 \mathrm{~h} \mathrm{(d),} 800{ }^{\circ} \mathrm{C}$ for $2 \mathrm{~h}(\mathrm{e}), 850{ }^{\circ} \mathrm{C}$ for $2 \mathrm{~h}$ (f). The isotherms a, b, c, d and e are offset vertically by 200, 170, 120, 80 and 40 $\mathrm{cm}^{3} / \mathrm{g}$, respectively. 


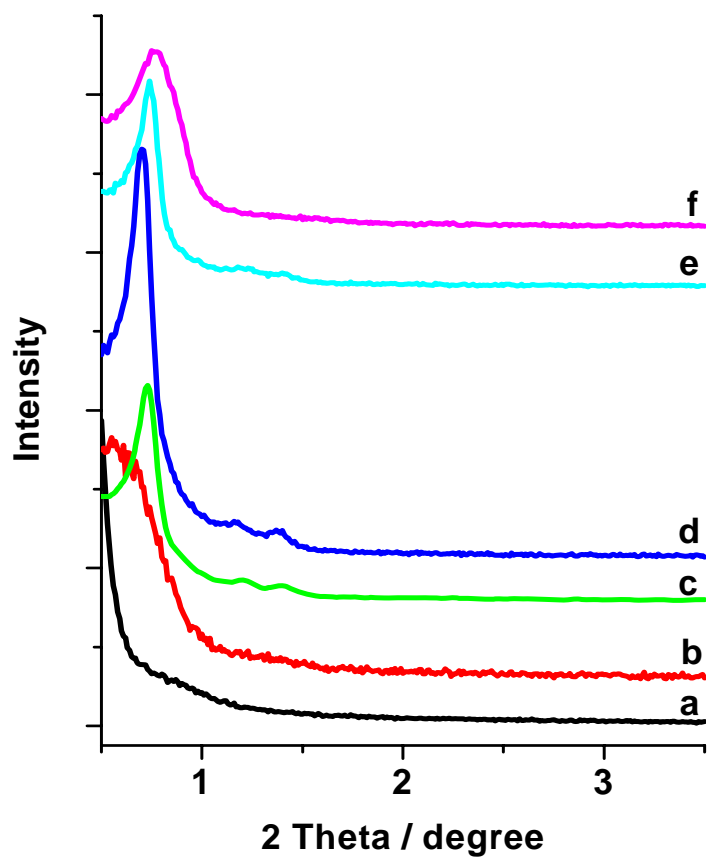

Figure S16. SAXRD patterns of the as-made mesostructured $80 \mathrm{TiO}_{2}-20 \mathrm{SiO}_{2}$ composites prepared under $50 \sim 60 \%$ of relative humidity and the evaporation temperature of $35{ }^{\circ} \mathrm{C}$ with adding different amount of concentrated $\mathrm{HCl}$, (a) $0.50 \mathrm{~g}$, (b) $1.0 \mathrm{~g}$, (c) $1.5 \mathrm{~g}$, (d) $2.2 \mathrm{~g}$, (e) $3.0 \mathrm{~g}$, (f) $3.7 \mathrm{~g}$, in the system of $2.34 \mathrm{~g}$ of TIPO, $0.434 \mathrm{~g}$ of TEOS, $1.0 \mathrm{~g}$ of triblock copolymer P123 and $30 \mathrm{~g}$ of ethanol absolute. 


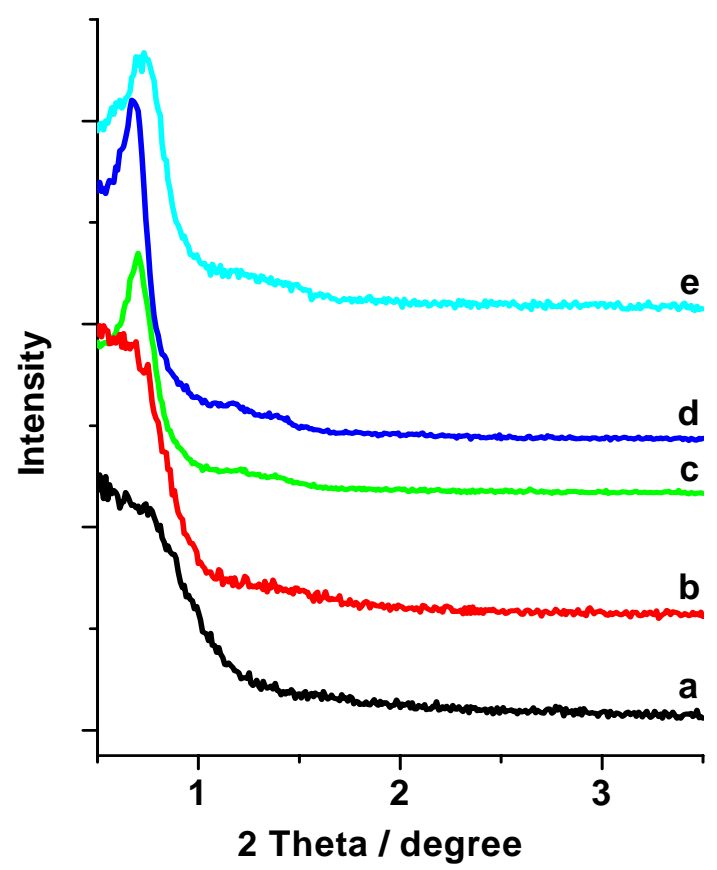

Figure S17. SAXRD patterns of the as-made mesostructured $70 \mathrm{TiO}_{2}-30 \mathrm{SiO}_{2}$ composites prepared under $65 \sim 80 \%$ of relative humidity and the evaporation temperature of $35^{\circ} \mathrm{C}$ with adding different amount of concentrated $\mathrm{HCl}$, (a) $0.50 \mathrm{~g}$, (b) $1.0 \mathrm{~g}$, (c) $1.5 \mathrm{~g}$, (d) $2.2 \mathrm{~g}$, (e) $3.0 \mathrm{~g}$, in the system of $2.05 \mathrm{~g}$ of TIPO, $0.652 \mathrm{~g}$ of TEOS, $1.0 \mathrm{~g}$ of triblock copolymer P123 and $30 \mathrm{~g}$ of ethanol absolute. 


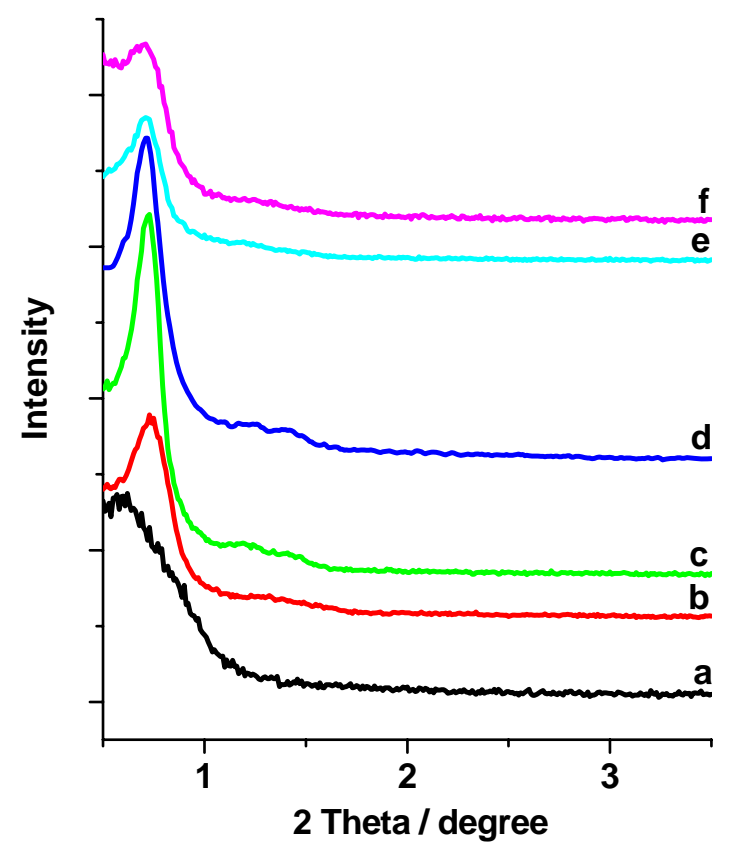

Figure S18. SAXRD patterns of the as-made mesostructured $60 \mathrm{TiO}_{2}-40 \mathrm{SiO}_{2}$ composites prepared under $65 \sim 80 \%$ of relative humidity and the evaporation temperature of $40{ }^{\circ} \mathrm{C}$ with adding different amount of concentrated $\mathrm{HCl}$, (a) $0.50 \mathrm{~g}$, (b) $1.0 \mathrm{~g}$, (c) $1.5 \mathrm{~g}$, (d) $1.8 \mathrm{~g}$, (e) $2.2 \mathrm{~g}$, (f) $3.0 \mathrm{~g}$, in the system of $1.76 \mathrm{~g}$ of TIPO, $0.868 \mathrm{~g}$ of TEOS, $1.0 \mathrm{~g}$ of triblock copolymer P123 and $30 \mathrm{~g}$ of ethanol absolute. 

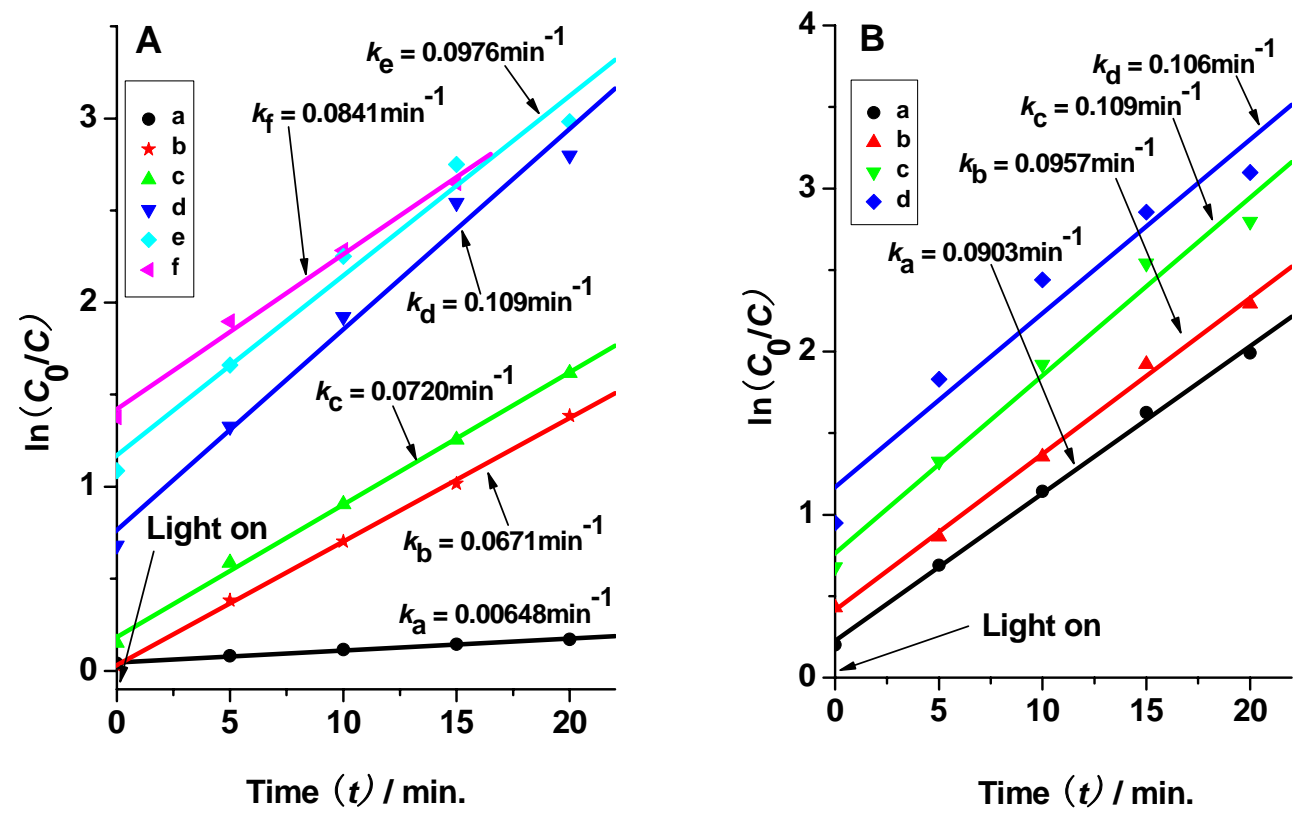

Figure S19. Photocatalytic degradation of $\mathrm{RhB}$ monitored as the $\ln \left(C_{0} / C\right)$ versus irradiation time in the presence of (A) mesoporous $\mathrm{TiO}_{2}-\mathrm{SiO}_{2}$ composites prepared with different $\mathrm{Ti} / \mathrm{Si}$ ratios. (a), Mesoporous $\mathrm{TiO}_{2}$ calcined at $400{ }^{\circ} \mathrm{C}$ for $2 \mathrm{~h}$; (b), commercial photocatalyst P25; (c), mesoporous $90 \mathrm{TiO}_{2}-10 \mathrm{SiO}_{2}$ composite calcined at $700{ }^{\circ} \mathrm{C}$ for $2 \mathrm{~h}$; (d), mesoporous $80 \mathrm{TiO}_{2}-20 \mathrm{SiO}_{2}$, (e), mesoporous $70 \mathrm{TiO}_{2}-30 \mathrm{SiO}_{2}$ and (f), mesoporous $60 \mathrm{TiO}_{2}-40 \mathrm{SiO}_{2}$ composites calcined in air at $850{ }^{\circ} \mathrm{C}$ for $2 \mathrm{~h}$, respectively. (B), Photocatalytic degradation on the mesoporous $80 \mathrm{TiO}_{2}-20 \mathrm{SiO}_{2}$ composites calcined in air at $700{ }^{\circ} \mathrm{C}$ for $4 \mathrm{~h} \mathrm{(a);} 800{ }^{\circ} \mathrm{C}$ for $2 \mathrm{~h}$ (b); $850{ }^{\circ} \mathrm{C}$ for $2 \mathrm{~h}$ (c); $900{ }^{\circ} \mathrm{C}$ for $2 \mathrm{~h}(\mathrm{~d})$, respectively. 